\title{
Knowledge and Compliance with Covid-19 Infection Prevention and Control measures among Health Workers in Regional Referral Hospitals in Northern Uganda: A cross-sectional Online Survey
}

Sharon Bright Amanya ( $\square$ amanya.sharonb@gmail.com )

Department of Microbiology and Immunology, Lira University https://orcid.org/0000-0001-6372-8910

Richard Nyeko

Department of Pediatrics and Child Health, Lira University

Bonniface Obura

Department of Pharmacology, Lira University

Joy Acen

Department of Midwifery, Lira University

Caroline Nabasirye

Department of Midwifery, Lira University

Florence Oyella

Department of Department of Pediatrics and Child Health, Gulu Regional Referral Hospital

\section{Victor Afayo}

Department of Obstetrics and Gynecology, Arua Regional Referral Hospital

\section{Mark Okwir}

Department of Internal Medicine, Lira University

\section{Research Article}

Keywords: Covid-19, Infection prevention, Infection control, health workers

Posted Date: August 24th, 2020

DOI: https://doi.org/10.21203/rs.3.rs-63627/v1

License: (c) (i) This work is licensed under a Creative Commons Attribution 4.0 International License.

Read Full License

Version of Record: A version of this preprint was published at F1000Research on April 12th, 2021. See the published version at https://doi.org/10.12688/f1000research.51333.2. 


\section{Abstract}

\section{Background:}

Infection prevention and control (IPC) has increasingly been underscored as a key tool for limiting the transmission of Covid-19 and safeguarding health workers from infections during their work. Knowledge and compliance with IPC measures is therefore essential in protecting health workers. However, this has not been established among Ugandan health workers in light of the Covid-19 pandemic.

Objective: To determine the knowledge and compliance with Covid-19 infection prevention and control measures among health workers in regional referral hospitals in Northern Uganda.

Methods: An online cross-sectional descriptive study was conducted among 75 health workers in regional referral hospitals within Northern Uganda. A structured questionnaire was distributed to health workers via WhatsApp messenger. Sufficient knowledge was considered at a correct response score of $\geq 80 \%$, while adequate compliance was rated $\geq 75$ of the maximum score. Data were analyzed using SPSS v21.

Results: The majority of the health workers had good knowledge (69\%) and compliance (68\%) with Covid19 IPC. Good compliance was significantly associated with training in Covid-19 IPC ( $p=0.039)$, access to Covid-19 IPC at work stations $(p=0.036)$, and having sufficient institutional support $(p=0.031)$. However, there was no significant relationship between knowledge and compliance with IPC $(p=0.007)$. The sociodemographic characteristics of health workers, including age, sex, education level, occupation, working hours and work experience, had no statistically significant relationship with Cvid-19 IPC knowledge or compliance.

Discussion: Our findings provide support for IPC training and guidelines as well as adequate PPEs to be available to health workers to improve compliance with Covid-19 IPC.

\section{Background}

Coronavirus Disease of 2019 (Covid-19) is arguably the greatest global health threat of our time. As of $9^{\text {th }}$ August, 19,462,112 people were infected globally, with more than 700,000 deaths(World Health Organization, 2020a). In Uganda, the cases are on the rise, with 18,379 cases as of $17^{\text {th }}$ August 2020(Ministry of Health Uganda, 2020a). As the cases rise, health workers are increasingly becoming at risk of infection as they care for the ever-so-growing number of Covid-19 patients. Uganda has thus far reported 49 cases of Covid-19 infection among health workers(Ministry of Health Uganda, 2020a), raising a concern that many more will become infected as the Covid-19 cases rise. Because the safety of health workers is key to winning the fight against the virus, infection prevention and control (IPC) measures remain critical tools. 
Recently, the World Health Organization (WHO) issued interim guidance on IPC that emphasized several measures, including applying standard precautions to all patients, ensuring early triage and case recognition, and applying additional precautions such as wearing masks (World Health Organization, 2020c). As the Covid-19 pandemic grows, countries have further stepped up IPC measures, including mandatory wearing of face masks and handwashing in all public places(Museveni, 2020, Ministry of Health Uganda, 2020b). Without compliance, however, these measures will not help in achieving the intended goal, and the health workers will increasingly be at risk of Covid-19 infection, a fact becoming evident in Uganda where health workers have been infected(WHO African Region, 2020).

Whereas Uganda has designated treatment sites for Covid-19 patients where rigorous IPC standards are implemented, some asymptomatic Covid-19 patients are likely to seek care from non-designated hospital departments where IPC measures might be inadequate. We believe that health workers in these departments are much more at risk of Covid-19 as they could be managing undiagnosed Covid-19 patents and therefore may not feel compelled to practice strict Covid-19 IPC measures. In this study, we evaluated the knowledge and compliance with Covid-19 IPC measures among health workers in regional referral hospitals in Northern Uganda.

\section{Methods}

\section{Study setting and design}

A descriptive cross-sectional online study was conducted among health workers at regional referral hospitals (RRHs) in Northern Uganda. The RRHs include Lira RRH, Arua RRH, and Gulu RRH, which serve as referral centers for the 30 districts in northern Uganda.

\section{Study population}

The study targeted health workers whose work involves primary contact with patients, including doctors, nurses, midwives, clinical officers, and laboratory officers.

\section{Study procedure and tool}

Purposive sampling was used to identify and select WhatsApp groups with the health workers of interest from the respective RRHs. The researchers obtained verbal consent from the group administrator and requested mobilizing members on the WhatsApp platforms. A link to the questionnaire on Google forms (Alphabet Inc., California, USA) was shared to the potential respondents via WhatsApp messenger (Facebook, Inc., California, USA). Participants randomly participated in the study by following the link shared.

Data were collected from 75 health workers using an anonymous, self-administered, online, structured questionnaire adapted from the literature. Knowledge and institutional support were assessed using an 8item questionnaire adapted from Haridi et al (Haridi et al., 2016) and modified to assess Covid-19 IPC knowledge among HCWs. Compliance was assessed using an 8-item questionnaire from the WHO 
protocol for the assessment of potential risk factors for Covid-19 infection among health care workers(World Health Organization, 2020d). The data collection tool consisted of 4 sections. The first section captured the demographic characteristics of the participants. The second section comprised eight questions ascertaining the level of knowledge and understanding of the concept of IPC and was scored as follows: One (1) point was awarded for each correct response and zero (0) for an incorrect response, and a correct response score of $\geq 80 \%$ was considered sufficient knowledge. The third section comprised eight questions to ascertain the level of compliance with IPC measures and scored as follows: 1, for 'never'; 2, for 'rarely'; 3, for 'sometimes'; and 4 for 'always', giving a total score of 32 points. Adequate compliance was set at $\geq 75 \%$ of the maximum score. The fourth section comprised three questions concerned with the perception of institutional commitment to IPC and was rated on a Likert scale (never, rarely, sometimes, and always). A scoring system was assigned as follows: 1, for 'never'; 2, for 'rarely'; 3 , for 'sometimes'; and 4 for 'always', giving a total score of 12. Strong institutional support was considered with a score of $\geq 75 \%$.

\section{Data management and analysis}

The responses from Google Forms were downloaded in an Excel sheet (Microsoft Inc. Albuquerque, New Mexico, United States) and then exported to Statistical Package for the Social Sciences (SPSS) software, version 21.0 (SPSS, Chicago, IL, USA) for analysis. Frequencies and percentages were used to summarize knowledge and compliance with IPC among HCWs, while means and standard deviations were used to summarize data on age, work experience and other numerical variables. The chi-square test was performed to determine the relationship between categorical variables, while the Pearson correlation test was used to determine the association between continuous variables. A variable was considered significant in this analysis if it had a p-value $<0.05$.

\section{Results}

\section{Demographic characteristics of respondents}

A total of 75 health care workers responded, and the majority were females (52\%). More than half of the respondents (60\%) belonged to the age group of $18-39$ years with a mean age of 36.92 (SD \pm 9.39$)$. The majority of the health workers interviewed had a bachelor's degree as their highest level of education and had a mean work experience of 10.4 years (SD \pm 8.79 ). Of all the participants, only $50.7 \%$ had received training in Covid-19 IPC, and 66.7\% reported having Covid-19 IPC guidelines at their work stations. A significant number of respondents (94.7\%) perceived themselves as being at risk of Covid-19 (Table 1).

\section{Table 1. Sociodemographic characteristics of respondents}




\begin{tabular}{|c|c|c|}
\hline Variable & Frequency (n) & Percentage (\%) \\
\hline \multicolumn{3}{|l|}{ Sex } \\
\hline . Male & 39 & 52 \\
\hline . Female & 36 & 48 \\
\hline Age (mean and SD) & 36.92 & 9.39 \\
\hline . $\quad 18$ to 39 & 45 & 60 \\
\hline . $\quad \geq 40$ & 30 & 40 \\
\hline \multicolumn{3}{|l|}{ Hospital } \\
\hline · $\quad$ Lira Regional Referral Hospital & 47 & 62.7 \\
\hline . $\quad$ Arua Regional Referral Hospital & 9 & 12 \\
\hline · $\quad$ Gulu Regional Referral Hospital & 19 & 25.3 \\
\hline \multicolumn{3}{|l|}{ Occupation } \\
\hline . $\quad$ Doctor & 17 & 22.7 \\
\hline . $\quad$ Nurse & 19 & 25.3 \\
\hline . Midwife & 22 & 29.3 \\
\hline - $\quad$ Clinical Officer & 12 & 16 \\
\hline . $\quad$ Laboratory Officer & 5 & 6.7 \\
\hline \multicolumn{3}{|l|}{ Level of education } \\
\hline . Certificate & 6 & 8 \\
\hline · $\quad$ Diploma & 21 & 28 \\
\hline . Bachelor's Degree & 47 & 62.7 \\
\hline . Master's Degree & 1 & 1.3 \\
\hline Work experience (Mean and SD) & 10.24 & 8.97 \\
\hline Working hours a week (mean and SD) & 47.6 & 15.09 \\
\hline \multicolumn{3}{|l|}{ Work station } \\
\hline . $\quad$ Medical ward & 13 & 17.3 \\
\hline$\cdot \quad$ OPD & 12 & 16 \\
\hline . $\quad$ Special Clinics & 3 & 4 \\
\hline - $\quad$ Pediatrics & 7 & 9.3 \\
\hline
\end{tabular}




\begin{tabular}{|lll|} 
· Obstetrics and Gynecology & 22 & 29.3 \\
· & 5 & 6.7 \\
Surgical ward & 5 & 6.7 \\
Neonatal unit & 4 & 5.3 \\
$\quad$ Laboratory & 4 & 5.3 \\
\hline IPC training for Covid-19 & & \\
Trained & 38 & 50.7 \\
Not trained & 37 & 49.3 \\
\hline Have Covid-19 IPC guidelines at work station & & \\
Have & 50 & 66.7 \\
Do not have & 25 & 33.3 \\
\hline Perceive risk of Covid-19 infection while at work & & \\
Yes & 71 & 94.7 \\
No & 0 & 0 \\
\hline May be & 4 & 5.3 \\
\hline
\end{tabular}

\section{Knowledge of Covid-19 infection prevention and control}

The majority of the respondents had good knowledge scores (69.3\%), with a mean knowledge score of 73.5 (SD \pm 13.15 ) (Table 2). Knowledge scores varied by item assessed. A vast majority of health care workers provided correct responses to items concerning the cleaning of frequently touched surfaces (97.3\%), use of contact precautions (94.7\%), screening for Covid-19 signs and symptoms (94.3\%), applicability of standard precautions (92\%), and cleaning of shared equipment (89\%). For items regarding airborne precautions (41.3\%) and applicability of hand hygiene $(57.4 \%$ and $76 \%)$, fewer correct respondents were noted (Table 3 ). There was no statistically significant relationship between knowledge and socio-demographic variables of respondents.

Table 2. Knowledge of Covid-19 Infection Prevention and Control among health care workers in regional referral hospitals in Northern Uganda 


\begin{tabular}{|lll|}
\hline Knowledge score & Frequency & Percentage \\
\hline Good knowledge & 52 & 69.3 \\
\hline Moderate knowledge & 21 & 28 \\
\hline Poor knowledge & 2 & 2.7 \\
\hline
\end{tabular}

Table 3. Knowledge score by item assessed among health workers at regional referral hospitals in Northern Uganda

\begin{tabular}{|lll|}
\hline Knowledge question & \multicolumn{2}{l|}{ Correct response } \\
\cline { 2 - 3 } & $\begin{array}{c}\text { Frequency } \\
\text { (n) }\end{array}$ & $\begin{array}{c}\text { Percentage } \\
\text { (\%) }\end{array}$ \\
\hline When should standard precautions be used & 69 & 92 \\
\hline The 5 moments when Hand hygiene' should be performed & 41 & 57.4 \\
\hline What is hand hygiene & 57 & 76 \\
\hline Contact Precautions require the use of & 71 & 94.7 \\
\hline Airborne precautions require the use of & 31 & 41.3 \\
\hline Shared clinical equipment do not need to be cleaned between patient use & 67 & 89.3 \\
\hline $\begin{array}{l}\text { All patients should be screened for Covid-19 signs and symptoms on } \\
\text { arrival }\end{array}$ & 71 & 94.3 \\
\hline $\begin{array}{l}\text { Frequently touched surfaces around a patient area (hospital) should be } \\
\text { cleaned at least daily }\end{array}$ & 73 & 97.3 \\
\hline
\end{tabular}

\section{Compliance with Covid-19 Infection Prevention and Control}

Compliance with Covid-19 IPC was high, with the majority of the participants (68\%) scoring more than $80 \%$ of the compliance score (Table 4 ) and varied by item assessed (Table 5). The mean compliance was 85.5 (SD \pm 10.3$)$ and was associated with having received training in Covid-19 IPC ( $p=0.039)$, having Covid-19 IPC guidelines at work stations $(p=0.036)$, and sufficient institutional support $(p=0.031)$. There was no statistically significant relationship seen between compliance and sociodemographic characteristics of participants such as age, level of education, working hours, work experience and health cadre. Additionally, compliance varied by parameter assessed (Table 5). 
Table 4. Compliance with Covid-19 Infection Prevention and Control among health workers in regional referral hospitals in Northern Uganda

\begin{tabular}{|lll|}
\hline Compliance & Frequency (n) & Percentage (\%) \\
\hline Good compliance & 51 & 68 \\
\hline Moderate compliance & 24 & 32 \\
\hline Poor compliance & 0 & 0 \\
\hline
\end{tabular}

Table 5. Compliance score by item assessed among health workers in regional referral hospitals in Northern Uganda

\begin{tabular}{|c|c|c|c|c|}
\hline \multirow[t]{2}{*}{ Item } & \multicolumn{4}{|l|}{ Responses } \\
\hline & $\begin{array}{l}\text { Always as } \\
\text { recommended }\end{array}$ & $\begin{array}{l}\text { Most } \\
\text { of the } \\
\text { time }\end{array}$ & Occasionally & Rarely \\
\hline $\begin{array}{l}\text { 1. Do you follow recommended hand hygiene } \\
\text { practices? }\end{array}$ & $38(50.7)$ & $\begin{array}{l}34 \\
(45.3)\end{array}$ & $3(4)$ & $0(0)$ \\
\hline $\begin{array}{l}\text { 2. Do you use alcohol-based hand rub or soap } \\
\text { and water before touching a patient? }\end{array}$ & $34(45)$ & $\begin{array}{l}36 \\
(48)\end{array}$ & $4(5.3)$ & $\begin{array}{l}1 \\
(1.3)\end{array}$ \\
\hline $\begin{array}{l}\text { 3. Do you use alcohol-based hand rub or soap } \\
\text { and water before cleaning/aseptic procedures? }\end{array}$ & $52(69.3)$ & $\begin{array}{l}19 \\
(25.3)\end{array}$ & $3(4)$ & $\begin{array}{l}1 \\
(1.3)\end{array}$ \\
\hline $\begin{array}{l}\text { 4. Do you use alcohol-based hand rub or soap } \\
\text { and water after (risk of) body fluid exposure? }\end{array}$ & $57(76)$ & $\begin{array}{l}18 \\
(24)\end{array}$ & $0(0)$ & $0(0)$ \\
\hline $\begin{array}{l}\text { 5. Do you use alcohol-based hand rub or soap } \\
\text { and water after touching a patient? }\end{array}$ & 43 (57.3) & $\begin{array}{l}28 \\
(37.3)\end{array}$ & $3(4)$ & (1.3) \\
\hline $\begin{array}{l}\text { 6. Do you use alcohol-based hand rub or soap } \\
\text { and water after touching a patient's } \\
\text { surroundings? }\end{array}$ & $32(42.7)$ & $\begin{array}{l}31 \\
(41.7)\end{array}$ & $11(14.7)$ & (1.3) \\
\hline $\begin{array}{l}\text { 7. Do you follow IPC standard precautions } \\
\text { when in contact with any patient? }\end{array}$ & $41(49.3)$ & $\begin{array}{l}31 \\
(41.3)\end{array}$ & $6(8)$ & $\begin{array}{l}1 \\
(1.3)\end{array}$ \\
\hline $\begin{array}{l}\text { 8. Do you wear PPE when indicated? (PPE } \\
\text { includes: Face mask, Face shield, Gloves, } \\
\text { Goggles/glasses,Gown, Cover-all, Head cover, } \\
\text { Respirator (e.g. N95 or equivalent),Shoe covers) }\end{array}$ & $28(37.3)$ & $\begin{array}{l}27 \\
(36)\end{array}$ & $2(13.3)$ & $\begin{array}{l}1 \\
(13.3)\end{array}$ \\
\hline
\end{tabular}

Institutional support for Covid-19 infection prevention and control 
Generally, there was strong perceived institutional support, with the majority of participants $(70.7 \%)$ feeling adequately supported by their respective institutions (Table 6). Moreover, adequate institutional support was associated with Covid-19 IPC compliance ( $\mathrm{p}=0.031)$. Just as knowledge and compliance, institutional support score varied by item assessed. For example, only $18.7 \%$ of the participants reported being availed adequate personal protective equipment (PPEs) by their hospitals, while $50.5 \%$ reported always having access to handwashing facilities and products, and $49.3 \%$ reported always being availed sufficient supplies for the collection of medical waste (Table 7).

Table 6. Institutional support for Coid-19 Infection Prevention and Control I regional referral hospitals in Northern Uganda

\begin{tabular}{|lll|}
\hline Item & Frequency & Percentage \\
\hline Adequate support & 53 & 70.7 \\
\hline Inadequate support & 22 & 29.3 \\
\hline
\end{tabular}

Table 7. Institutional Support for Covid-19 Infection Prevention score by item assessed

\begin{tabular}{|c|c|c|c|c|}
\hline Item & Always & $\begin{array}{l}\text { Some } \\
\text { times }\end{array}$ & Rarely & Never \\
\hline $\begin{array}{l}\text { 1. Provision of Adequate Personal protective Equipment } \\
\text { (PPEs) eg. Gloves, masks, Aprons etc }\end{array}$ & $\begin{array}{l}14 \\
(18.7)\end{array}$ & $\begin{array}{l}34 \\
(45.3)\end{array}$ & $\begin{array}{l}26 \\
(34.7)\end{array}$ & $\begin{array}{l}1 \\
(1.3)\end{array}$ \\
\hline $\begin{array}{l}\text { 2. Availability of hand-washing facilities with clean running } \\
\text { water and hand hygiene products }\end{array}$ & $\begin{array}{l}38 \\
(50.7)\end{array}$ & $\begin{array}{l}24 \\
(32)\end{array}$ & $\begin{array}{l}13 \\
(17.3)\end{array}$ & $0(0)$ \\
\hline $\begin{array}{l}\text { 3. Provision of sufficient supplies for the collection of } \\
\text { sharps and medical wastes }\end{array}$ & $\begin{array}{l}37 \\
(49.3)\end{array}$ & $\begin{array}{l}34 \\
(45.3)\end{array}$ & $\begin{array}{l}4 \\
(5.3)\end{array}$ & $0(0)$ \\
\hline
\end{tabular}

\section{Discussion}

Our findings suggest that the majority of the health workers in RRHS in Northern Uganda are knowledgeable and compliant with Covid-19 IPC. We have identified that $69.3 \%$ of the respondents have good knowledge of Covid-19 IPC and that it varied by item assessed. Whereas limited data exist on knowledge of Covid-19 IPC among health workers in Africa, our findings are comparable to those of a similar study at a Chinese mental institution that showed a knowledge score of 63.9\%(Yang et al., 2020). However, pre-Covid-19 pandemic studies have shown lower knowledge scores(Geberemariyam et al., 2018, Sahiledengle et al., 2018). Taken together, these findings imply that training in IPC during the Covid19 pandemic has enhanced health workers' IPC knowledge and therefore needs to be sustained.

Moreover, similar to previous studies(Russell et al., 2018, Haridi et al., 2016, Ibrahim and Elshafie, 2016), we demonstrate that knowledge on various parameters of IPC varies, with most health workers less 
knowledgeable about parameters related to airborne precautions and hand hygiene. This deficiency in knowledge suggests a need to focus on training, audit and feedback methods to improve knowledge in these areas, as they are central Covid-19 IPC. Furthermore, we did not find a statistically significant relationship between knowledge and participants' sociodemographic characteristics, IPC training or presence of guidelines. However, previous studies have reported a positive association between knowledge of IPC and age, years of experience, training in IPC, and availability of guidelines (Russell et al., 2018, Desta et al., 2018). One possible reason for this discrepancy is the context in which the studies were conducted. Unlike these previous studies, our study was conducted during the Covid-19 pandemic, where health workers have been exposed to various training and information sources regarding IPC in the setting of Covid-19.

We also found that the majority of the health workers had good compliance (68\%) with Covid-19 IPC measures. The high score of self-reported compliance is comparable to a previous self-report study (Russell et al., 2018). However, previous studies that used observation methods for data collection reported compliance rates with hand hygiene (53-57\%)(Geberemariyam et al., 2018, Desta et al., 2018, Yang et al., 2020). This discrepancy could be due to the difference in methods, as self-reported studies are likely to find more compliance with IPC. Moreover, compliance scores also varied by item assessed, as reported in previous studies(Powell-Jackson et al., 2020, Bedoya et al., 2017). In addition, compliance was found to be associated with having had training in Covid-19 IPC, having IPC guidelines, and perceived strong institutional support. Previous studies have shown that training in IPC and access to guidelines improves compliance with IPC (Sahiledengle et al., 2018, Desta et al., 2018, Geberemariyam et al., 2018). Accordingly, the WHO and the Uganda Ministry of Health (Ministry of Health Uganda, 2020b, World Health Organization, 2020b) have emphasized training of all health care staff and developed and supplied guidelines for IPC. These efforts are likely to have contributed to the high knowledge and compliance scores noted in our study. Therefore, our findings provide support for the notion that support to health care workers in terms of training, provision of guidelines and appropriate facilities and supplies for IPC increases compliance.

In the present study, we also report adequate institutional support (70\%) reported by health workers. Despite the high scores, fewer health workers reported adequate provision of PPEs. Indeed, inadequate supply of PPEs has been a key challenge in health care systems worldwide during this pandemic, with policy makers advocating for the provision of more PPEs to protect health care workers(Cooper et al., 2020). In this regard, Uganda is not spared as the Covid-19 cases and hospital admissions continue to grow. Currently, there are 18,379 reported cases, 49 of which are among health workers(Ministry of Health Uganda, 2020a). Our findings point to the need for an adequate and consistent supply of PPEs to RRHs in Northern Uganda. Nonetheless, the small sample size coupled with the self-report method of measuring compliance are key limitations of this study, and we therefore suggest that further studies consider observation methods to improve the objectivity of the data.

\section{Declarations}




\section{Acknowledgement}

We acknowledge the hospital administrators who enabled access to the target population as well as the health care workers for sparing time to participate in the study.

\section{Declarations}

Ethical approval was obtained from St. Mary's Hospital Lacor, and written informed consent was obtained from all participants prior to participation in the study.

The authors report no conflicting interests in this study.

There was no specific funding for this study.

\section{References}

BEDOYA, G., DOLINGER, A., ROGO, K., MWAURA, N., WAFULA, F., COARASA, J., GOICOECHEA, A. \& DAS, J. 2017. Observations of infection prevention and control practices in primary health care, Kenya. Bulletin of the World health Organization, 95, 503.

COOPER, S., WIYEH, A., SCHMIDT, B.-M. \& WIYSONGE, C. S. 2020. Cochrane corner: factors that influence compliance by healthcare workers with infection prevention and control guidelines for COVID-19 and other respiratory infections. The Pan African Medical Journal, 35.

DESTA, M., AYENEW, T., SITOTAW, N., TEGEGNE, N., DIRES, M. \& GETIE, M. 2018. Knowledge, practice and associated factors of infection prevention among healthcare workers in Debre Markos referral hospital, Northwest Ethiopia. BMC health services research, 18, 465.

GEBEREMARIYAM, B. S., DONKA, G. M. \& WORDOFA, B. 2018. Assessment of knowledge and practices of healthcare workers towards infection prevention and associated factors in healthcare facilities of West Arsi District, Southeast Ethiopia: a facility-based cross-sectional study. Archives of Public Health, 76, 69.

HARIDI, H. K., AL-AMMAR, A. S. \& AL-MANSOUR, M. I. 2016. Compliance with infection control standard precautions guidelines: a survey among dental healthcare workers in Hail Region, Saudi Arabia. Journal of infection prevention, 17, 268-276.

IBRAHIM, A. A. \& ELSHAFIE, S. S. 2016. Knowledge, awareness, and attitude regarding infection prevention and control among medical students: a call for educational intervention. Advances in medical education and practice, 7, 505.

MINISTRY OF HEALTH UGANDA 2020a. Covid-19 Situation report 17th August, 2020. Sitrep \#181 ed. Kampala, Uganda: Ministry of Health. 
MINISTRY OF HEALTH UGANDA 2020b. UGANDA MINISTRY OF HEALTH COVID-19 INFECTION PREVENTION AND CONTROL GUIDANCE FOR HIV SERVICES DELIVERY

MUSEVENI, Y. K. 2020. Updates on matters regarding Coronavirus (Covid-19) ON 18th May 2020. In: HOUSE, S. (ed.). Nakasero.

POWELL-JACKSON, T., KING, J. J., MAKUNGU, C., SPIEKER, N., WOODD, S., RISHA, P. \& GOODMAN, C. 2020. Infection prevention and control compliance in Tanzanian outpatient facilities: a cross-sectional study with implications for the control of COVID-19. The Lancet Global Health.

RUSSELL, D., DOWDING, D. W., MCDONALD, M. V., ADAMS, V., ROSATI, R. J., LARSON, E. L. \& SHANG, J. 2018. Factors for compliance with infection control practices in home healthcare: findings from a survey of nurses' knowledge and attitudes toward infection control. American journal of infection control, 46, 1211-1217.

SAHILEDENGLE, B., GEBRESILASSIE, A., GETAHUN, T. \& HIKO, D. 2018. Infection prevention practices and associated factors among healthcare workers in governmental healthcare facilities in Addis Ababa. Ethiopian journal of health sciences, 28, 177-186.

WHO AFRICAN REGION 2020. Covid-19 Situateion Update for the WHO Africa Region, External Situation Report-23. World Health Organization.

WORLD HEALTH ORGANIZATION 2020a. Coronavirus Disease (Covid-19) Situation Report-202.

WORLD HEALTH ORGANIZATION 2020b. Infection prevention and control during health care when COVID19 is suspected: interim guidance, 19 March 2020. World Health Organization.

WORLD HEALTH ORGANIZATION 2020c. Infection prevention and control during health care when novel coronavirus ( $\mathrm{nCoV}$ ) infection is suspected: interim guidance, January 2020. World Health Organization.

WORLD HEALTH ORGANIZATION 2020d. Modes of transmission of virus causing COVID-19: implications for IPC precaution recommendations: scientific brief, 27 March 2020. World Health Organization.

YANG, M., WANG, H., LI, Z., ZHANG, Q., LIU, X., HE, M. \& GAO, S. 2020. Prevention and Control of COVID-19 Infection in a Chinese Mental Health Center. Frontiers in medicine, 7. 